\title{
HUBUNGAN USIA DAN PARITAS DENGAN KEJADIAN PREEKLAMSI BERAT DI RSUD IBNU SOETOWO BATURAJA KABUPATEN OGAN KOMERING ULU TAHUN 2014
}

\author{
Siska Delvia \\ Siska.delvia26@gmail.com \\ Dosen STIKES Al-Ma'arif Baturaja
}

\begin{abstract}
Abstrak
Latar Belakang: prevalensi angka kejadian Preeklampsia berat di dunia mencapai 0,51\%-38,4\% dan preeklamsi merupakan penyebab kematian perinatal yang paling tinggi, Tujuan: untuk mengetahui hubungan usia dan paritas dengan kejadian preeklamsi berat di RSUD Ibnu Soetowo Baturaja Kabupaten Ogan Komering Ulu tahun 2014. Metode: penelitian ini menggunakan metode analitik dengan pendekatan cross sectional. Populasi penelitian ini adalah ibu bersalin yang rawat inap di Instalasi kebidanan RSUD Ibnu Soetowo Baturaja, dengan sampel pengambilan sampel secara random sampling. Analisa data menggunakan analisa univariat dan analisa bivariat dengan menggunakan tabel distribusi dan uji statistik Chi-Square, dengan derajat kepercayaan 95\%. Hasil penelitian: pada analisa univariat, dari 287 responden didapat responden yang mengalami preeklamsi berat sebesar $18,8 \%$, responden dengan usia ibu hamil resiko tinggi sebesar $21,3 \%$, dan responden dengan paritas beresiko sebesar $16 \%$. Analisa bivariat di dapatkan hasil ada hubungan antara usia ibu hamil dengan kejadian preeklamsi berat ( $p$ value 0,000$)$, dan ada hubungan antara paritas dengan kejadian preeklamsi berat ( $p$ value 0,000). Simpulan: ada hubungan usia ibu dan paritas dengan kejadian preeklamsi berat.
\end{abstract}

Kata Kunci : preeklamsi berat, usia ibu dan paritas, cross sectional, uji statistik Chi-Square,

\begin{abstract}
Background: Program development of immunization is one of the activities that receive priority in the national health system, which aims to protect babies and toddlers from PD3I (disease can be prevented by immunization), such as tuberculosis, diphtheria, pertussis, tetanus, and measles. Objective: to know the relation between knowledge and mother work toward booster immunization of children under five in the Work Area UPTD Kemalaraja OKU District Health Center in 2015. Methods: This study uses an analytical method with cross sectional approach. This study population is children under the age of 1-5 years who bring their babies to Posyandu in the Work Area Health Center Kemalaraja UPTD District of West Baturaja OKU District, with samples sampling sampling acidental. Data were analyzed using univariate and bivariate analysis using the statistical distribution tables and Chi-Square test, with a $95 \%$ degree of confidence. Result: the univariate analysis, of 81 respondents obtained $63 \%$ of children who received booster immunizations, mother good knowledge $53.1 \%$, and a mother who worked at $54.3 \%$. The bivariate analysis results get no relationship to the mother's knowledge booster immunization ( $\mathrm{p}$ value 0.000 ), and no relation to the mother's occupation booster immunization ( $p$ value 0.000). Conclusion: there is a relationship of knowledge and work towards the provision of the booster immunization in children under five.
\end{abstract}

Keywords: booster immunization, mother's knowledge and work, cross-sectional, statistical test Chi-Square 
1. PENDAHULUAN

Menurut

World

Health

Organization (WHO), Angka kematian Ibu (AKI) tahun 2013, sebesar 81\% yang diakibatkan oleh komplikasi dalam kehamilan, persalinan dan nifas. Bahkan sebagian besar dari kematian ibu disebabkan karena perdarahan, infeksi dan preeklamsi (Afandi, 2013).

Sedangkan angka kejadian preeklamsia menurut WHO berkisar antara 0,51\%-38,4\%. Zuspan dan Arulkumaran juga melaporkan angka kejadian Preeklamsia didunia sebesar 013\%, dan di Singapura sebesar 0,136,6\%. Angka kejadian preeklamsia Indonesia sebesar 3,4-8,5\%. Dari penelitian Soejoesnoes di 12 rumah sakit rujukan di dapatkan kasus preeklampsia 4,78\% dan kasus eklampsia 0,15\%. Jika diurutkan berdasarkan umur dan paritas, maka ditemukan kelompok umur $<20$ dan >35 tahun sebanyak 72,72\%, sedangkan berdasarkan paritas pada primipara yaitu 81,81\% (Fauziah, 2013).
Jumlah angka kematian ibu di negara-negara ASEAN menurut Depkes tahun 2010 jika dibandingkan AKI Singapura adalah 6 per 100.000 kelahiran hidup, AKI Malaysia mencapai 160 per 100.000 kelahiran hidup. Bahkan AKI Vietnam sama seperti Negara Malaysia, sudah mencapai 160 per 100.000 kelahiran hidup, Filipina 112 per 100.000 kelahiran hidup, Brunei 33 per 100.000 per kelahiran hidup (Fitriani, 2014).

Di Indonesia Angka kematian ibu (AKI) tercatat mencapai 359 per 100 ribu kelahiran hidup. Rata-rata kematian ini jauh melonjak dibanding hasil SDKI 2007 yang mencapai 228 per 100 ribu (Fauziah, 2014).

Di dalam rencana strategi nasional Making Pregnancy Safer (MPS) di Indonesia 2001-2010, bahwa visi dari MPS adalah kehamilan dan persalinan di Indonesia berlangsung aman, serta bayi yang dilahirkan hidup dan sehat (Saifuddin, 2002). Salah satu sasaran 
yang ditetapkan untuk tahun 2015 adalah menurunkan angka kematian maternal menjadi $75 \%$ dari AKI tahun 1990 (Fauziah, 2013).

Yang menjadi sebab utama kematian ibu di Indonesia di samping perdarahan adalah pre-eklampsia atau eklampsia yang merupakan penyebab kematian perinatal yang tinggi. Preeklampsi ialah penyakit dengan tandatanda hipertensi, edema dan proteinuria yang timbul karena kehamilan, penyebabnya belum diketahui. Pada kondisi berat preeklamsia dapat menjadi eklampsia dengan penambahan gejala kejang-kejang (Arianti, 2012).

Pada tahun 2013 di Sumatera Selatan tercatat $17,55 \%$ ibu hamil dengan faktor resiko termasuk ibu hamil dengan preeklampsia. AKI di Sumsel tahun 2011: sebesar 133 kematian/100 ribu, tahun 2012, sebesar 149 kematian/100 ribu dan tahun 2013, sebesar 146 kematian/100 ribu (Fitriani, 2014).
Preeklamsi merupakan penyakit yang khusus terjadi pada kehamilan dan lebih berakibat buruk pada sang ibu dari pada terhadap sang bayi. Penyakit ini hanya terjadi pada tiga bulan terakhir dari suatu kehamilan dan ditandai dengan adanya oedema (pembengkakan pada kulit, dan jelas sekali pada pergelangan kaki ataupun lengan dan wajah) (Fauziah, 2013).

Menurut Sunarsih (2011) faktor resiko terjadinya preeklamsia pada kehamilan adalah: usia, paritas, ras/golongan etnik, faktor keturunan, faktor gen, diet/gizi, iklim, tingkah laku/ sosial ekonomi, dan hiperplasentosis.

Data yang di dapat di Rumah Sakit Umum Daerah Ibnu Soetowo jumlah preeklamsia pada tahun 2012 adalah sebanyak 81 orang dari 1022 ibu bersalin, tahun 2013 kejadian preeklamsi sebanyak 124 dari 1321 ibu bersalin dan tahun 2014 kejadian preeklamsi sebanyak 133 dari 1011 ibu bersalin. Bila dilihat dari data tersebut kejadian preeklamsi di Rumah Sakit Umum 
Daerah Ibnu Soetowo dari tahun 20122014 mengalami peningkatan.

Berdasarkan latar belakang diatas peneliti tertarik untuk melakukan penelitian dengan judul Hubungan Usia dan Paritas dengan Kejadian Preeklamsi Berat di RSUD Ibnu Soetowo Baturaja Kabupaten Ogan Komering Ulu Tahun 2014.

\section{METODE PENELITIAN}

\section{Jenis Penelitian}

Penelitian ini menggunakan metode survey analitik dengan pendekatan cross sectional dimana variabel independen dan variabel dependen diteliti secara bersamaan, dikumpulkan pada suatu saat (Point Time Approach) dan tiap-tiap subjek penelitiannya di observasi satu kali saja (Hidayat, 2010).

\section{Populasi dan Sampel Penelitian}

\section{a. Populasi}

Populasi penelitian ini adalah ibu bersalin yang rawat inap di Instalasi kebidanan RSUD Ibnu Soetowo Baturaja pada saat penelitian tahun 2014 dengan jumlah 1011 ibu bersalin.

\section{b. Sampel}

Sampel adalah sebagian yang diambil dari keseluruhan objek yang diteliti dan dianggap mewakili populasi. Dalam penelitian ini menggunakan metode random sampling dengan rumus Notoadmodjo, yaitu:

$$
n=\frac{N}{1+N\left(d^{2}\right)}
$$

Keterangan $: \mathrm{n}=$ Besar

Sampel

$$
\mathrm{N}=\text { Jumlah }
$$

Populasi

$$
\mathrm{d}=\text { Tingkat }
$$

kepercayaan $($ sebesar $5 \%=0,05)$

Dengan menggunakan rumus tersebut, maka banyaknya sampel yang diperoleh adalah:

$$
n=\frac{N}{1+N\left(d^{2}\right)}
$$

$$
n=\frac{1011}{1+1011\left(0,05^{2}\right)}
$$


$n=\frac{1011}{3,5275}$

$\mathrm{n}=286,7$ dibulatkan menjadi 287 sampel.

\section{c. Lokasi dan Waktu Penelitian}

\section{Tempat Penelitian}

Penelitian akani dilakukan di RSUD

Ibnu Soetowo Baturaja Kabupaten OKU.

\section{Waktu Penelitian}

Penelitian akan dilaksanakan dari bulan April-Mei tahun 2015.

\section{d. Teknik dan Instrumen Pengumpulan}

\section{Data}

\section{Teknik Pengumpulan Data}

Tekhnik pengumpulan data menggunakan data Sekunder.

\section{Alat/ Instrumen Pengumpulan Data}

Alat pengumpulan data dalam penelitian ini adalah dengan menggunakan check list.

\section{e. Teknik Pengolahan Data}

Pengolahan data dilakukan dengan cara sebagai berikut:

\section{Editing (pengkodean)}

Merupakan kegiatan untuk

melakukan pengecekkan isi kuisioner apakah jawaban yang ada sudah lengkap, jelas, relevan dan konsisten.

\section{Coding (pengeditan data)}

Merupakan kegiatan merubah data berbentuk huruf menjadi data berbantuk angka/ bilanagan.

\section{Processing (pemasukan data)}

Memasukkan data yang diperoleh dengan menggunakan komputer.

\section{Cleaning Data (pembersihan data)} Merupakan proses pengecekan kembali data untuk konsistensi dan treatmen yang hilang.

\section{f. Analisis Data}

\section{Analisis Univariat}

Analisa ini dilakukan untuk mengetahui distribusi frekuensi variabel independen (usia dan paritas) dan variabel dependen (Preeklamsi Berat). 


\section{Analisis Bivariat}

Analisa ini dilakukan untuk melihat hubungan variabel yang diteliti yaitu variabel independen (usia dan paritas) dan variabel dependen (Preeklamsi Berat). Adapun uji yang digunakan adalah uji statistik Chi Square dengan derajat kepercayaan $95 \%$ dengan tingkat kemaknaan $(\alpha)$ sebesar 5\% atau 0,05. Bila $p$ value $\leq 0,05$ menunjukkan ada hubungan bermakna dan jika $p$ value $>0,05$ menunjukkan tidak ada hubungan bermakna antara variabel independen dan dependen.

\section{HASIL PENELITIAN}

\section{Analisa Bivariat}

Analisa ini dilakukan untuk mengetahui hubungan antara variabel independen (usia dan paritas) dengan variabel dependen (kejadian preeklamsi berat). Uji statistik yang digunakan adalah uji chi-square dengan batas kemaknaan $p$ value $\leq 0,05$ artinya ada hubungan yang bermakna (signifikan) dan bila $p$ value $>0,05$ maka tidak ada hubungan yang bermakna.

\section{Usia}

Dari hasil perhitungan uji statistik chisquare dengan derajat kemaknaan $95 \%$ hubungan usia dengan kejadian preeklamsi berat dapat dilihat pada tabel di bawah ini.

Tabel 5.4 Hubungan Usia Dengan Kejadian Preeklamsi Berat di RSUD Ibnu Soetowo Baturaja Kabupaten Ogan Komering Ulu Tahun 2014

\begin{tabular}{|c|c|c|c|c|c|c|c|c|}
\hline \multirow{3}{*}{ No } & \multirow{3}{*}{ Usia } & \multicolumn{4}{|c|}{ Kejadian Preeklamsi Berat } & \multirow{3}{*}{$\Sigma$} & \multirow{3}{*}{$\%$} & \multirow{3}{*}{$\begin{array}{c}p \\
\text { value }\end{array}$} \\
\hline & & \multicolumn{2}{|c|}{$\mathrm{Ya}$} & \multicolumn{2}{|c|}{ Tidak } & & & \\
\hline & & $\mathrm{F}$ & $\%$ & $f$ & $\%$ & & & \\
\hline 1. & $\begin{array}{l}\text { Resiko } \\
\text { Tinggi }\end{array}$ & 39 & 63,9 & 22 & 36,1 & 61 & 100 & \\
\hline 2. & $\begin{array}{l}\text { Tidak } \\
\text { Resiko } \\
\text { Tinggi }\end{array}$ & 15 & 6,6 & 211 & 93,4 & 226 & 100 & 0,000 \\
\hline & Jumlah & 54 & 18,8 & 233 & 81,2 & 287 & 100 & \\
\hline
\end{tabular}


Berdasarkan Tabel 5.4 diketahui bahwa dari

61 responden yang mengalami preeklamsi berat dengan usia resiko tinggi sebanyak 39 responden $(63,9 \%)$, dan usia yang tidak resiko tinggi yang mengalami preeklamsi berat sebesar 15 responden $(6,6 \%)$.

Hasil uji statistik Chi-Square menunjukkan bahwa ada hubungan yang bermakna antara usia ibu hamil dengan kejadian preeklamsi berat dengan $p$ value 0,000 . Dikatakan ada hubungan karena nilai $\quad p$ value $\leq 0,05$

\section{Paritas}

Dari hasil perhitungan uji statistik chisquare dengan derajat kemaknaan $95 \%$ hubungan paritas dengan kejadian preeklamsi berat dapat dilihat pada tabel di bawah ini.

Tabel 5.5 Hubungan Paritas Dengan Kejadian Preeklamsi Berat di RSUD Ibnu Soetowo Baturaja Kabupaten Ogan Komering Ulu Tahun 2014

dengan demikian hipotesa diterima.

\begin{tabular}{|c|c|c|c|c|c|c|c|c|}
\hline \multirow{3}{*}{ No } & \multirow{3}{*}{ Paritas } & \multicolumn{4}{|c|}{ Kejadian Preeklamsi Berat } & \multirow{3}{*}{$\Sigma$} & \multirow{3}{*}{$\%$} & \multirow{3}{*}{$\begin{array}{c}p \\
\text { value }\end{array}$} \\
\hline & & \multicolumn{2}{|c|}{$\mathrm{Ya}$} & \multicolumn{2}{|c|}{ Tidak } & & & \\
\hline & & $\mathrm{F}$ & $\%$ & $\mathrm{f}$ & $\%$ & & & \\
\hline 1. & Beresiko & 40 & 87 & 6 & 13 & 46 & 100 & \\
\hline 2. & $\begin{array}{l}\text { Tidak } \\
\text { Beresiko }\end{array}$ & 14 & 5,8 & 227 & 94,2 & 241 & 100 & 0,000 \\
\hline & Jumlah & 54 & 18,8 & 233 & 81,2 & 287 & 100 & \\
\hline
\end{tabular}

Berdasarkan Tabel 5.5 diketahui bahwa dari

46 responden yang mengalami pre eklamsi berat dengan paritas beresiko tinggi sebanyak 40 responden (87\%), dan paritas dengan $p$ value 0,000. Dikatakan ada hubungan karena nilai $\quad p$ value $\leq 0,05$.

\section{A. KESIMPULAN}

Dari hasil penelitian yang telah tidak beresiko yang mengalami preeklamsi berat sebesar 14 responden $(5,8 \%)$. dilaksanakan di RSUD dr. Ibnu Soetowo Baturaja Kabupaten OKU tahun 2014, Hasil uji statistik Chi-Square menunjukkan tentang hubungan usia dan paritas bahwa ada hubungan yang bermakna antara 
dengan kejadian preeklamsi berat, dapat ditarik kesimpulan sebagai berikut:

1. Hasil distribusi frekuensi responden yang mengalami pre-eklamsi berat sebesar 54 responden $(18,8 \%)$.

2. Hasil distribusi frekuensi dan persentase responden usia ibu yang beresiko tinggi sebesar 61 responden $(21,3 \%)$.sedangkan hasil distribusi frekuensi responden usia ibu tidak resiko tinggi sebesar 226 responden $(78,7 \%)$.

3. Hasil distribusi frekuensi dan persentase responden dengan paritas beresiko tinggi sebesar 46 responden (16\%).sedangkan hasil distribusi frekuensi responden dengan paritas tidak beresiko tinggi sebesar 241 responden $(84 \%)$.

4. Ada hubungan usia dengan kejadian preeklamsi Berat di RSUD Ibnu Soetowo Baturaja Kabupaten Ogan Komering Ulu Tahun 2014. Hal tersebut dibuktikan pada nilai uji statistik dengan nilai $p$ value 0,000 .

5. Ada hubungan paritas dengan kejadian preeklamsi Berat di RSUD
Ibnu Soetowo Baturaja Kabupaten Ogan Komering Ulu Tahun 2014. Hal tersebut dibuktikan pada nilai uji statistik dengan nilai $p$ value 0,000 .

\section{B. SARAN}

Sesuai dengan hasil penelitian yang penulis lakukan maka penulis memberikan beberapa masukkan untuk membantu dalam meningkatkan pelayanan kesehatan ibu dan anak, sebagai berikut :

\section{Bagi Peneliti}

Dapat mengapikasikan ilmu yang di dapat selama kuliah dan sebagai pembelajaran langsung di lapangan.

2. Bagi Instansi Pendidikan

Hasil penelitian ini diharapkan dapat dijadikan sebagai acuan untuk melakukan penelitian dan perlu dilakukan penelitian lebih lanjut untuk mencari faktor-faktor lain yang berhubungan dengan kejadian preeklampsia.

3. Bagi Tenaga Kesehatan

Mengingat bahwa umur dan paritas adalah faktor determinan potensial dari kejadian preeklampsia, maka 
perlu memberikan pengawasan anternatal yang baik, deteksi dini dan penanganan yang adekuat.

\section{DAFTAR PUSTAKA}

Afandi. 2013, Hubungan Preeklamsi dan Hipertensi Gestasional dengan Berat Badan Lahir Bayi di RSUD Raden Matter Jambi. Jurnal Kedokteran.

Arianti. Djannah. 2012, Gambaran Epidemiologi Kejadian Preeklamsia/Eklamsia di RSU PKU Muhammadiyah Yogyakarta Tahun 2012. Jurnal Kedokteran.

Asrul. 2008. Metodologi Penelitian Kedokteran dan Kesehatan Masyarakat. Jakarta. Binurupa Aksara

Bandiyah. Siti. 2013, Kehamilan, Persalinan dan Gangguan Kehamilan. Erlangga, Jakarta.

Data RSUD Ibnu Soetowo. 2014, Data Ibu Bersalin dan Preeklamsi. Kabupaten OKU.

Fauzi. Arif. 2013. Buku Panduan Perawatan Kehamilan. Keen Book. Yogyakarta.

Fauziah.Wulandari. 2013. Faktor Resiko Kejadian Preeklamsia Berat pada Ibu Hamil di RSUD dr.Moewardi Surakarta. Jurnal Kesehatan Masyarakat.

Fitriani. Idil. 2014,Hubungan antara Umur dan Paritas dengan Kejadian Preeklamsia di Rumah Sakit DR. Mohammad Hoesen Palembang. Jurnal Kesehatan.
Hidayat.Alimul. 2010. Metode Penelitian Kebidanan dan Teknik Analisa Data. Salemba Medika. Jakarta

Kemenkes. 2013. Pedoman Penyelenggaraan Puskesmas Mampu PONED. Kemenkes. Jakarta

Kuswanti, Ina. 2013. Asuhan Kehamilan. Media Pressind.Yogyakarta

Manuaba, 2008. Ilmu Kebidanan, Penyakit Kandungan dan Keluarga Berencana untuk Pendidikan Bidan. Jakarta, EGC 2010. Memahami Kesehatan Wanita. Jakarta, EGC

Prawiroharjo. Sarwono. 2011. Ilmu Kandungan. PT Bina Pustaka Sarwono Prawiroharjo. Jakarta

Purwanti. 2014. Pastikan Anda dan Janin Anda Sehat. .Mitra Setia.

Raymond. Tjandrawinata. 2014, Medicinus Hepatic Encephalopathy. Contribution. Jakarta

Saptono. Irawan. 2013, Jalan Terjal Menurunkan Angka Kematian Ibu. Tifa. Jakarta

Sunasih. 2011, Faktor Resiko Terjadinya Preeklamsia Pada Kehamilan Kabupaten Batu Bara Tahun 2011, Jurnal Kesehatan 